\title{
ネコの視床背内側核の皮質投射に関する 実験解剖学的研究
}

\author{
岡山大学医学部第三解剖学教室（指導：新見教授）
}

友成 正二

（昭和52年10月28日受稿）

\begin{abstract}
諸言
背内側核は視床の内側部にあり，外方は内瞇板に よって取り团まれている，ての核は皮質結合を持た ないと言う人もあったが(Sachs's3), Monakow191 は すでに背内側核と前頭葉の間の線維結合を七トで予 想していた. Minkowski ${ }^{189}$ はサルで背内側核から前 頭葉の前頭極に及ぶような庢範な領域に達する求皮 質線維を記載した. Clark" も背内側核と前頭皮質 領域との間の直接の線維関係を認め, しかも哺乳類 の系統発生では前頭皮質（前頭前野）の進化的発育 と, 背内側核の進化的分化の間には密接な平行関係 があると言っている．その後，背内側核の皮質結合 については実験的に多くの人によって研究された。

1933 年に Clark と Boggon ${ }^{5}$ はネコでMarchi 法 と逆行性細胞変性法を用いて背内側核の皮質結合を 研究し，この核か前頭前野，外側，中間およひ内側 眼筒野によって代表される前頭葉の顆粒皮質に投射 するてとを見出した。

その後, 逆行性細胞変性法を用いてネコの背内側 核の皮質投射が多くの人によって研究された (Waller と Barris,' Waller, ${ }^{42)}$ Rose と Woolsey, ${ }^{311}$ Warren ら“)）.さらにサルを用いて Mettler, Bonin と Green,' Pribram 5,", Scollo-Lavizzari $と$ Akert, Akert ${ }^{1 /} ら か ゙$, 1 又用いて Narkiewicz と Brutk一 owski ${ }^{201}$ が逆行性細胞変性法で研究した. Nauta と Gygax $^{22}{ }^{22}$ が変性軸索鍍銀法を発表して以来, 多くの 人はこの方法およびその変法(Fink-Heimer ${ }^{8)}$ 法)を 用いるようになったすすなわらネコを用いて Nauta そ Whitlock, Khalifeh 5,, Wells, ${ }^{(2)}$ 田中 ${ }^{35}$ らか背 内側核の皮筫投射を研究した。最近では Leonard, ${ }^{13)}$
\end{abstract}

Domesick Ђがラットを用いて研究している.さら

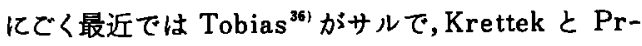
ice ${ }^{133}$ がラットでオートラシオグラフィー法で研究 し，また Beckstead ${ }^{2}$ はラットでパーオキシデース 法で研究している.

著者はネコを用いて視床背内側核の皮質投射を Nauta-Gygax ${ }^{22)}$ 法およびその変法(Fink-Heimer ${ }^{81}$ 法）に上って詳しく追求し，特にその投射の局在を 明らかにする目的でての研究を行った。

\section{研究材料と方法}

この研究には 13 匹の成熟ネコを用いた. Nembutal 麻醉のもとに定位手術装置 (David Kopf 製)の助け をかりて左側の視床背内側核の各部を電気的化壊 した，電極は同側 (左側)の大脳半球を通つて垂直に 插入し(Cats 17，34，35，33，18，27)，あるいは右 側の大脳半球から前頭面で斜めに腹内側方に插入 して反対側(左側)の背内側核在破壊した (Cats 53, $39,30,22,37,4,32)$. 傷は $2 \mathrm{~mA}$ の面流を $15 ２ 0$ 秒通電して作った. 手術後 $6 \sim 7$ 日生存ののち, 過 量の Nembutal によって麻酔し，まず生理的食塩水 で頝動脈を通して潅流し，ついで $10 \%$ 中性ホルマ リン液で潅流して殺した，睬を頭蓋腔より摘出し， $10 \%$ ホルマリン液で固定した. 5 日後てれらの脳を 前頭面で約 $10 \mathrm{~mm}$ の厚さに切って粗大ブロックとし た. 脳を粗大ブロックに切る前およびその後て脳の 外側面を写真に撮影した。 さらに脳を $10 \%$ ホルマ リン液で 1 か月間固定した後,水結ミクロトームで 厚さ $40 \mu$ の横断連続切片を作製した。 その切片の うち 1 / 4 の切片を大部分 Nauta-Gygax 法, 一部 Fink-Heimer 法で鍍銀した。 なお背内側核の傷を含 
むレベルにおける他の 1 / 4 の切片をクレシール・ パイオレットで染め，傷の位置と広がりを決めろの に用いた. 実験例の大部分では Nauta 法で鍍銀した 切片の一部をクレシール・バイオレットで後染した. なお電極を同側から垂直に择入して背内側核に達し， または電極を反対側から斜めに挿入し，脳梁を通過 または通過せずに背内側核に達した例について，電 流を通さずに対照実験を行った。なお，なats 27，30， 32 は教室所蔵の標本を用いた。

背内側核における傷の位置と広がりはクレシール ・バイオレット染色の適当な横断切片から画き，そ の傷の矢状方向における広がりはグラフ式復元法を 用いて画いた. すべての電極の通過経路を組織学的 に検查した。

皮質投射の検索には万能投影機（日本光学製）で 6 枚おきの切片を 5 倍に拡大した像をケント紙に とり，その上に変性終末の分布を記入した．特に皮 罆におけろ終末の存在する部位はその密度によって 3段階に分かち，それをもとにしてグラフ式復元図 を作製した。

定位手術装置で傷を作るためにはJasper と Ajmone-Marsan" ${ }^{11}$ のコの図譜を用いたが，視床核 の分類ことに背内側核の境界と区分は Niimiと Kuwahara ${ }^{25}$ のネコの視床の細胞構築的研究に従つ た. かれらは背内側核を内側部, 背側部, 外側部お よび腹側部に分けている．また前頭葉皮質の細胞構 筑的区分はほほ Gurewitch と Chatschaturian ${ }^{109} お$ よび Roseと Woolsey" に従った。

\section{所見}

\section{Cat 53 (図 1)}

この例における傷は小さく，左側の背内側核の前 端部にあり, 主としてその内側部の背側の部分およ び背側部の前端部を障害しているが，一部外側部の 背側端をも傷つけている. 電極は右側の大脳半球を 斜めに貫好き(約 $\left.25^{\circ}\right)$ ，左側の紐傍核を通って背内 側核に達していろ. 睬梁は貫通されていない，傷は 一部内側前核の後部の内側部に及んでいる.

佰から出た線維の一部は内側方に走って正中核に 向かうが，大部分は腹側ないし腹外側方に束をなし て走り，中心㥬核，内側腹側核などを貫好く，一部 は外側方に走って内側前核を通過するるのもある。 大部分の線維は内側腹側核を通過しつつ前方に進み, 視床網様核の腹内側部を通過する．変性線維はさら に前腹側方に進み,外側視床下部核の前端部および外
側視索前核を通って腹外側方に向かい，尾状核頭の 腹側端部の外側縁と，てれ亿接した内包の前脚の部 分を通ってしだいに腹内側方に向かい, 対角带を通 って大部分の線維は前背側方に走って内側面皮質に 向かうが, 一部の線維は外側方に放散し, 舟状回の 外側面の後端部に達し, それぞれ舟状回の内側面お 上び外側面皮質に分布する.

舟状回におけろ変性線維の分布は比較的散在性で, その分布範囲は舟状回の内側面および外側面のそれ それ前腹側部に広がる。特に舟状回の前縁部，すな わち内側面と外側面の境界部では変性線維がやや多 く, しか子外側面上りも内側面の方㱙多少ひろく広 がろ. 比較的小さい傷を有するてのような背内側破 壊例で変性線䧽の分布が非常に広い範囲に広がり, かなり散在性であるととは注目される。

背内側核から出ろ線維はかなり細く，皮兵内では 主として第 4 層およひ第 3 層の深部に分布するが, 変性の著明な皮質部では第 1 首の表層部にも少数 の変性線維が見られる.なお第 4 層では表面に平 行に走る変性線維がかなり見られるのが特徽的であ 万(図 14).

\section{Cat39 (図 2)}

この例の侮は背内側核の前部および中央部の高さ で，その内側部に限局する．電極は反対側(右側)の 大脳半球を斜めに貫ぬき(約 $20^{\circ}$ ), 左側の前室傍核 を通って背内側核の内側部の中心部および内側の部 分を傷つけている. 電極は途中で脳梁を通過してい ない，前室傍核の一部は傷に含まれている。

背内側核加ら出て内側面皮質に分布する線維は外 側面皮質に向かう6のよりもやや多い：この例にお けろ皮質変性域は外側面ではほとんど舟状回の大部 分に広がるが, 内側面皮質ではほぼその腹側半に限 局し, 分野 6 のすぐ腹側にある分野 32 の背側部は 皮質変性を示していない，最も強い変性域蛙内側面 の腹側端部にあり，とれはわずか外側面皮質に及ん でいろ. 中等度の変性域は強い変性域の周囲を取り 巻く. 外側面皮質では前嗅满をやや越えて多少背側 方に広がる. 蹯な弱い変性域は内側面および外側面 とも中等度の変性域を背側方から取り囲むが, 内側 面皮質ではその背側半にはほとんど広がらない：ま た外側面皮質では疎な変性域は Sylvius 前清の付 近およびその下壁には広がらない，ての例では皮質 変性域は内側面おょび外側面ともに前の例よりもか なり後方に広がり, 内側面では分野 12 の大部分を おおう。 


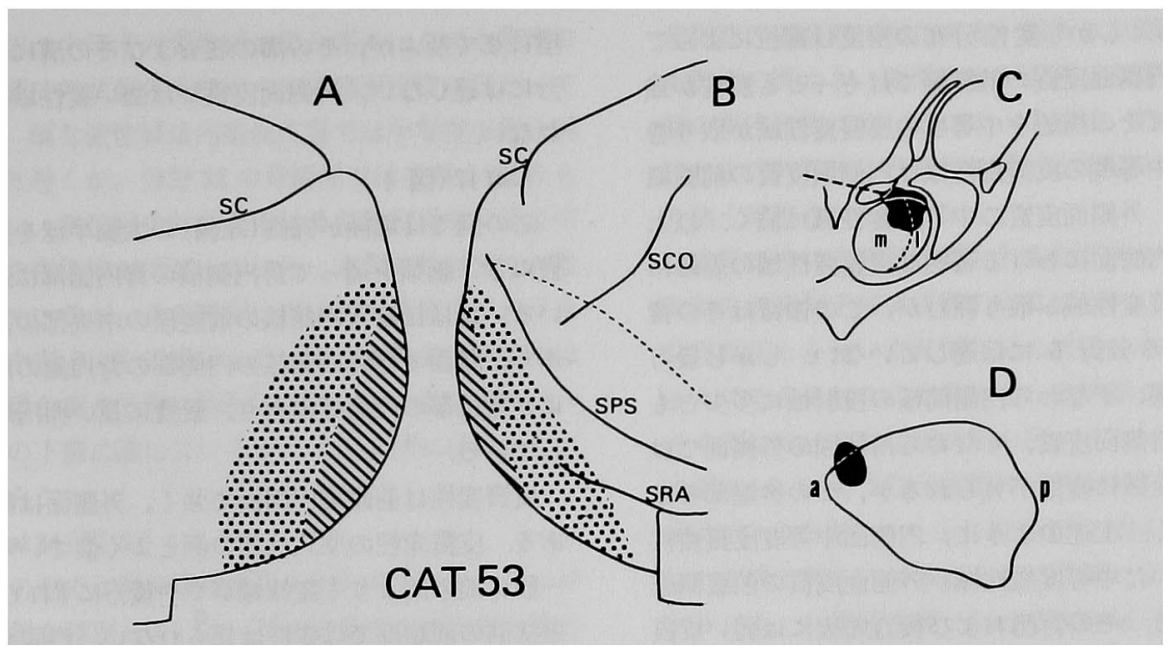

図 1 Cat 53. 大脳半球前部の内側面 (A) と外側面 (B)におけろ皮質変性の分布と視 床背内側核の横断面 (C) および外側面投影図 (D) における傷の位置と広がりを示す。 $\mathrm{A}, \mathrm{B}$ において斜線は中等度の変性, 点は弱い変性を示し, 点線はシルビウス前溝の 底を示す. Clおいて破楾は電極の刺入方向を示す. $\mathrm{a}$, 前; p, 後; d, 背内側核の背側 部; l, 外側部; $m$, 内側部; $v$, 腹側部; SC, 十字溝; SCO, 冠状溝; SPS, シルビウ ス前溝; SRA, 前嗅溝.

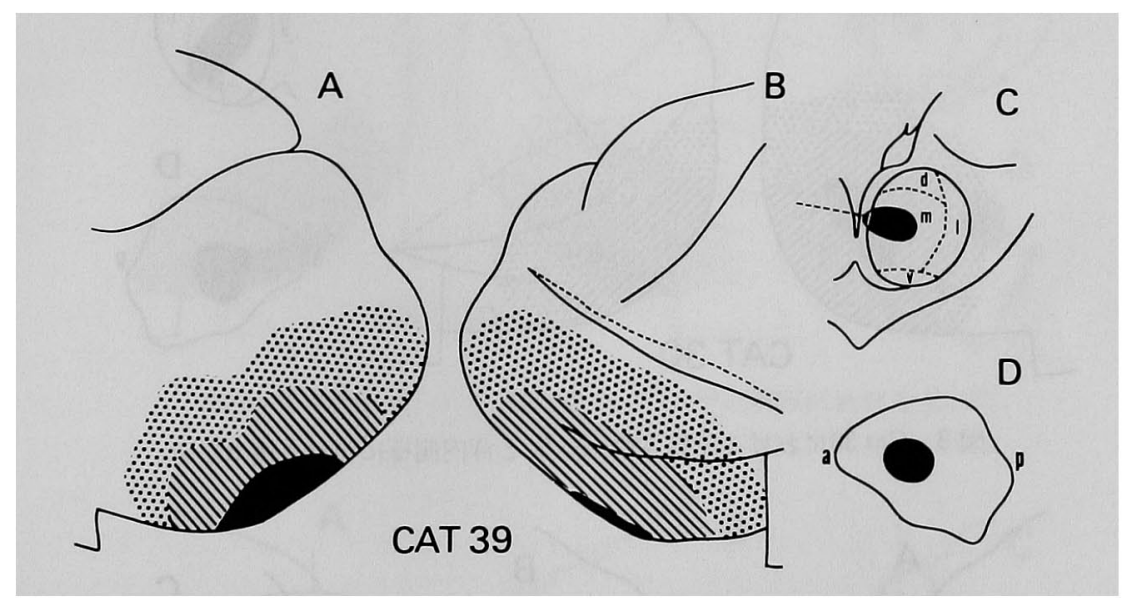

図 2 Cat 39におけろ皮質変性 $(A, B)$ と背内側核の傷 (C, D). A, Bにおいて黒は強い 変性, 斜線は中等度の変性, 点は弱い変性を示す。

\section{Cat30 (図 3)}

この列におけろ傷は左側の背内側核の前後径にお けるほほ中央部にあり,前の例よりもかなり大きく， 断面では背内側核の内側部にほほ限局して斜めに長 軸を向けた長棈円形を呈しているが，外側部の腹側 端にわずか波及していろ. 電極は右側の大脳半球を

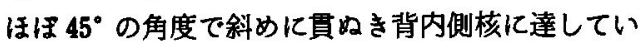
ろ. 途中で脳梁の一部を通過，障害していろ. しか
しそのために起てろ皮質変性は背内側核の傷による 皮質変性域と離れていろので, 両者の区別は容易で ある.

この例では前頭葉内側面皮質に向かう線維は外側 面皮質に向かうものよりもかなり多い，内側面皮質 における変性域は非常に広く,分野 6 より腹側の内 側面皮質のほとんど全域に広がり，ほほ背内側核の 全投射域に及んでいる（分野 $8 ， 32$ および分野 24 と 
12 の一部). しかし変性分布の密度は部位によって 異なる. 内側面皮質の前腹側ではもっとも変性が強 く,さらにその周辺を中等度の皮質変性域が取り巻 く. この中等度の皮質変性域は内側面皮質の前腹側 縁をへて, 外側面皮質の中等度変性域に続く，以上 のような内側面における著明な皮賈変性域の周辺に は弱い皮賈変性域が取り囲むが，この領域はその背 側における分野 6 には達していない. しかし後方 は前辺縁部，すなわち内側前核の投射域に多少とも 広がる．外側面皮質，すなわち舟状回の外側面では ほとんど全域に変性が見られるが，その後端部では 変性を欠く，上述のように，内側面中等度皮質変性 域から続いた中等度変性域が外側面皮質の前腹側部 に見られろ. その背側および後方周辺には弱い皮質 変性域か取り巻く.との変性域は Sylvius 前溝の下
壁にまで及ぶが，その溝の底およびその溝に近い部 分には達しない，外側面皮質では強い変性域は見ら れない。

Cat 17 (図 4)

この例では電極が同側 (左側) の大脳半球を垂直に 貫妨き, 脳梁を通って背内側核の背内側部に達して いる，傷はほぼ背内側核の前後径の中央部の高さに あり，断面では背内側核の内側部の背内側の部分お よび背側部の内側端にあり，腹背に長い卵円形を呈 している.

皮質変性は前頭葉内側面で強く，外側面は軽微で ある. 皮質変性の型式は前の例とよく似ていろが, 一般に前の例よりも変性域がやや後方にずれていて， 舟状回の前端部では変性は見られない．内側面皮質 では最も強い変性はその腹側部の中央部にあり，そ

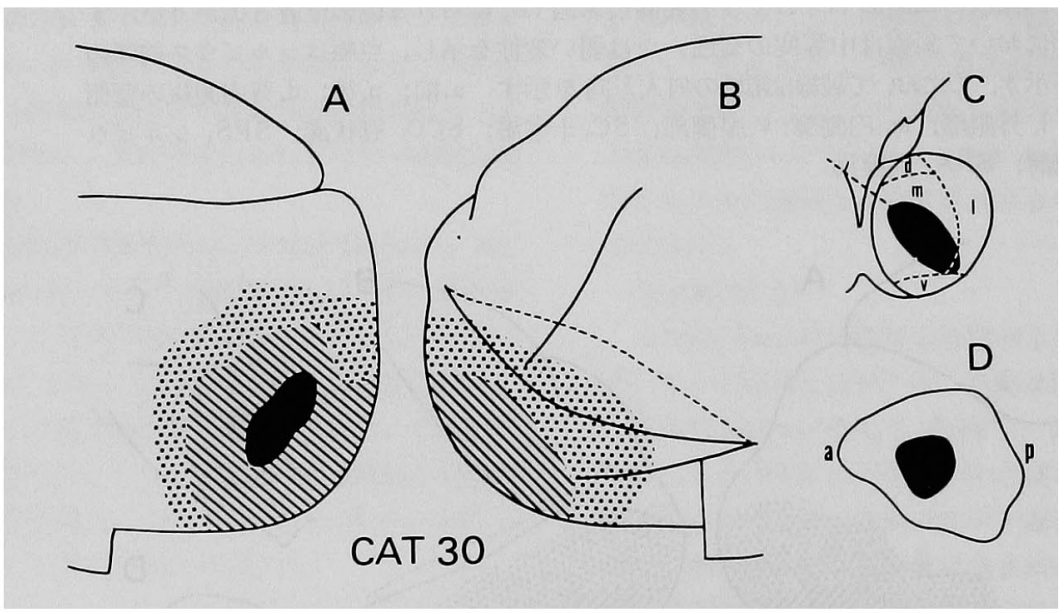

図 3 Cat 30における皮質変性 $(A, B)$ と背内側核における傷 $(C, D)$.

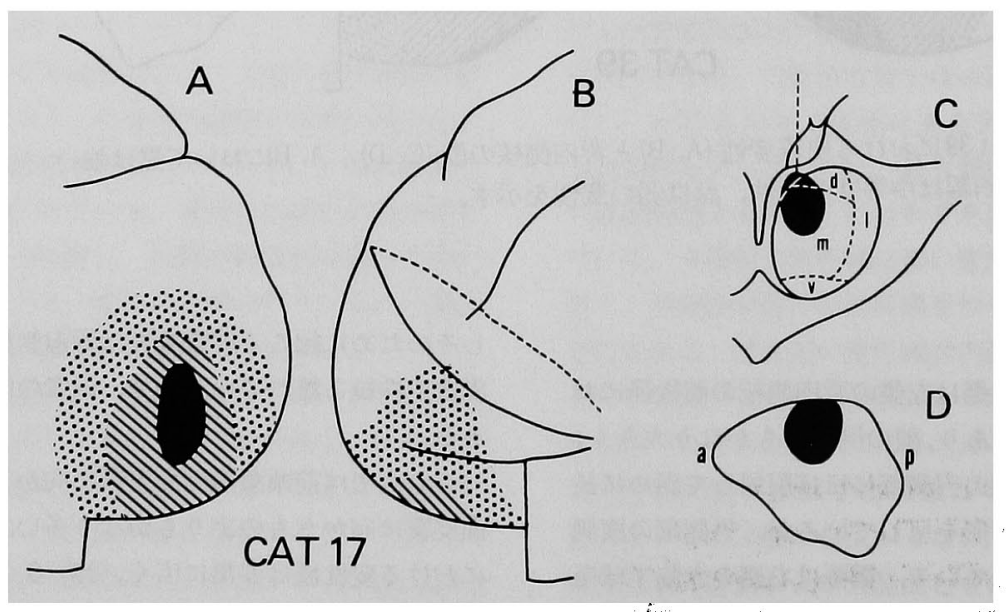

図4Cat17における皮質変性 (A, B) と背内側核における傷 (C, D). 
の周辺は中等度の変性域が取り囲み, との中等度の 変性域は前頭葉の下縁をへて外側面皮質に広がって いろ. 柾な変性域は内側面皮質では中等度の変性域 を取り巻くが, 分野 32 の背側部では変性が認めら れない. 舟状回の外側面ではその腹側端部に多少中 等度の変性域が広がっている. 大部分疎な変性が散 在していろが，その範囲は舟状回の前後径における ほほ中央 $1 / 3$ に限局していろ. 少数の変性線維は 前喚溝を越えて多少背側方に広がり，一部は Sylvius 前溝の下唇に達しているが，その下壁にははとんど 広がらない。

Cat 34 (図 5)

この例では傷は背内側核の後部の高さで, その背 内側部を障害していろ. 特に内側部の背内側の部分 および背側部の内側の部分を含む. この高さはほほ
背側部の後端部に相当する. 電極は左側の大脳半球 を垂直に貫ねき，脳梁および手綱核を貫通して，同 側の背内側核に達していろ. 手綱核, 特にその内側 核および外側核の内側部の部分が電極によってかな り強く障害されている.

皮質変性は内側面皮質と外側面皮質の腹側部，す なわち前頭葉下縁の周囲の皮質に強い.内側面およ び外側面とも強い皮筫変性域の周辺に中等度変性, さらにそのまわりには疎な㐷い変性域が取り囲む. この例における変性域は前の例にくらへてやゃ後方 に偏り，しかす外側面皮質では内側面皮質と同様に 変性がかなり強く,てとに䂾な変性域は Sylvius 前 溝の下唇を越えて多少ともその下壁に広がるのが注 目される.内側面皮質における変性域の背側方への 広がりは弱い。

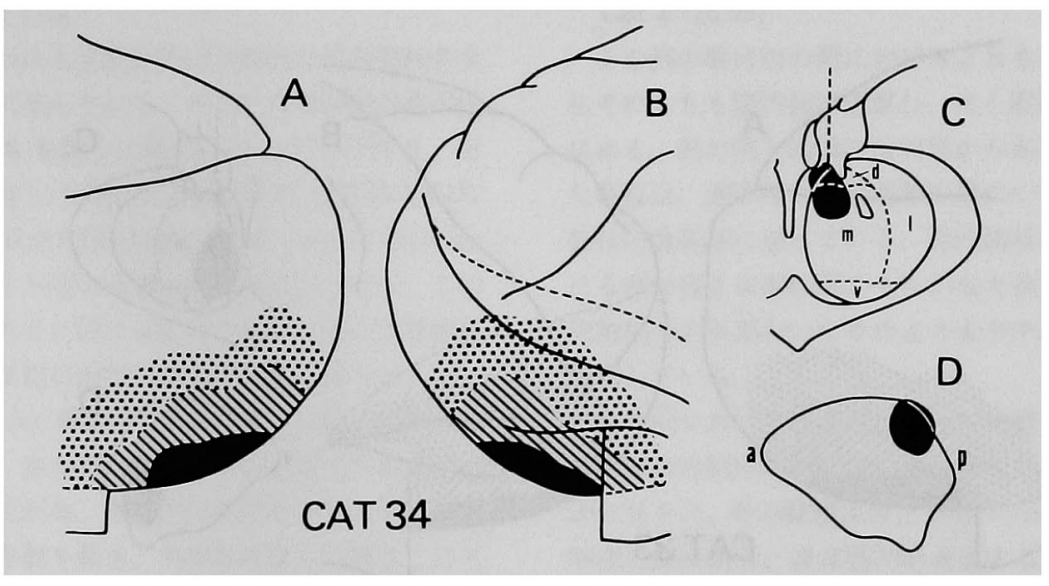

図 5 Cat 34におけろ皮質変性 (A, B) と背内側核におけろ(C, D).

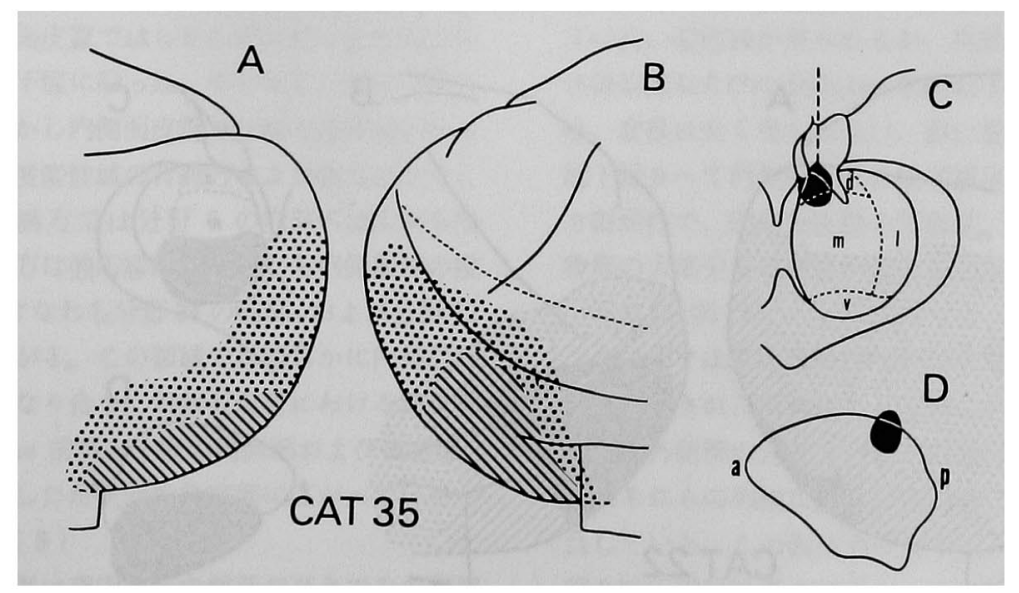

図6 Cat 35における皮質変性 (A, B) と背内側核における傷 $(C, D)$. 


\section{Cat 35 (図 6)}

この例におけろ傷は Cat 34 と同様に垂直に挿入さ れた電極によって作られ，その傷は Cat 34 のそれと ほほ同じ位置にあるが，それよりもかなり小さい。 すなわち Cat 34 の傷よりもわずか前方の高さで背内 側核の背側部の内側の部分およびそれに近接した内 側部の一部が障害されている.

この例では傷はかなり小さいにもかかわらず，皮 質変性域はかなりひろい範囲に広がっている．著明 な変性は舟状回の外側面皮質ではその前後径のほほ 中央部から後部にかけて見られろ. との変性域はか

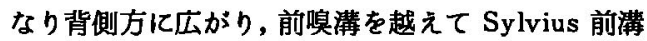
に近づくが，その下唇にははとんど達しない，ての 著明な変性域は前頭葉の下縁をへて内側面に広がり, 内側面腹側端部に前後にやや長い変性域を作ってい
ろ. 弱い変性域は著明な変性域の周囲を取り巻き, 特に前上方にかなり強く広がる. 舟状回外側面では 特にその前部おょび Sylvius 前溝の下壁の外側部に 広がっている。

\section{Cat33 (図 7 )}

この例においても電極は同側の大脳半球を垂直に 貫好き脳梁および手網核を通って同側の背内側核 の内側および腹内側部を障害していろ. 傷の大部分 は背内側核の内側部の範囲にあるが，一部腹側部の 内側端部を傷つけていろ. との傷はかなり大きく， 背腹に長い卵円形を呈していろ. この傷は背内側核 の後部の高さから後端部の高さにかけてあろ.

最 強い皮質変性域は内側面と外側面皮質の境界 部，すなわち前頭葉下縁のまわりに見られろが，前 の例よりかなり後方に偏っている．との強い変性域

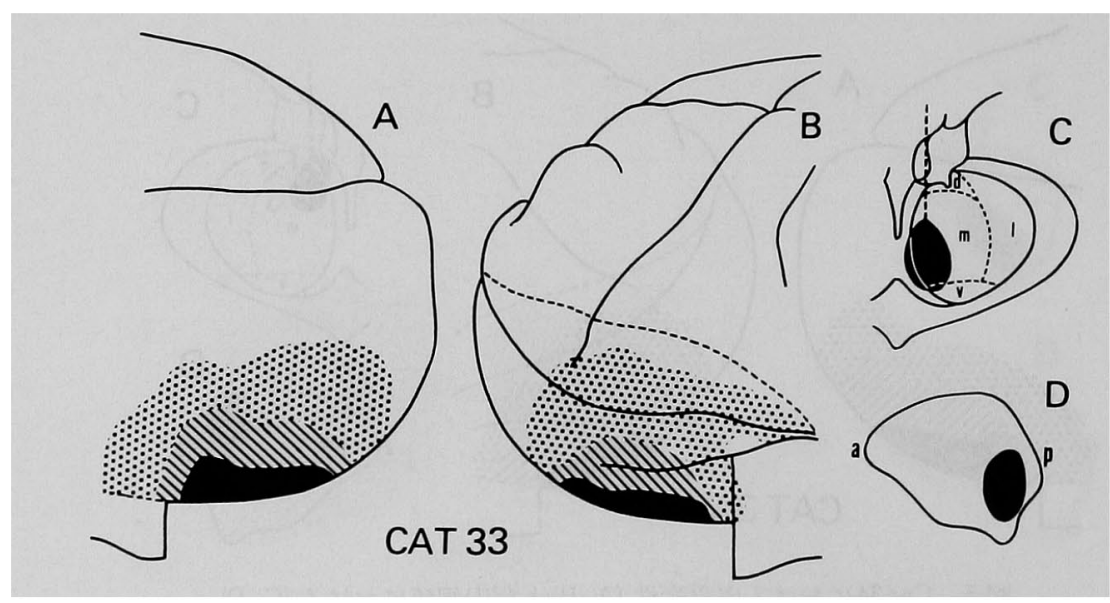

図 7 Cat 33におけろ皮質変性 $(A, B)$ と背内側核における傷 $(C, D)$.

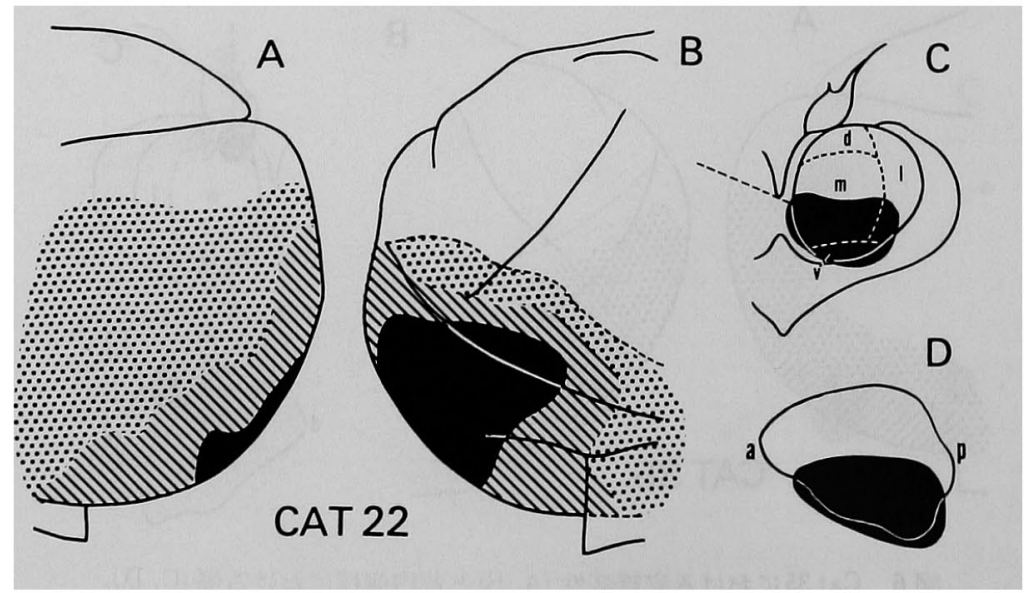

図 8 Cat 22における皮質変性 $(A, B)$ と背内側核における傷 $(C, D)$. 
のまわりには中等度の変性域およびさらにその周囲 に疎な変性域が取り巻くが, 全体として内側面およ び外側面とも背側方への広がりが前の例より強い． すなわちこの例では内側面皮質におけろ変性域はほ とんどその腹側半を占めろ. 外側面皮質では Sylvius 前满の下唇をへてかなり強く下壁に広がろが，ての 溝の底に達することはない。

Cat22 (図 8)

この例の傷は非常に大きく，背内側核の前部から 後端部に及び，断面では背内側核の内側部の腹側半， 腹側部の全域および外側部の腹内側の部分に広がっ ている. 電極は反対側(右側)の大兴半球からほほ $30^{\circ}$ の角度で斜めに挿入され，前および後室傍核の 腹側端部を通り，左側の背内側核に入ろ.この傷は 背内側核の腹側および腹外側にある中心傍核の一部 をも包含している。

との例における皮質変性域の範囲は背内側核の全 皮質投射域に及んでいろ.すなわち前頭葉内側面皮 質では分野 6 を除く大部分, 寸なわち分野 8 , 分 野 32 , 分野 12 の大部分および分野 24 の前部に及び, 外側面皮質では舟状回の全域(分野 8 )および Sylvius 前溝の下唇と下壁のほとんど全域に広がるが，ての 溝の底を越えて上壁には広がらない，強い皮質変性 域は外側面皮質の前部および中央部に見られろが, 一部は Sylvius 前溝の下唇を越えて下壁の腹側部に 達している. また前頭葉の前下緣を越えて多少内側 面皮質にも広がろ. 中等度の変性域はこの強い変性 域のまわりを取り巻き，外側面皮質では露出した舟 状回のほとんど全域および Sylvius 前溝の下壁の外 側部および中央部はとのような著明な変性域で占め られろ. 内側面皮質ではしかし中等度の変性域はそ の前縁および下縁に沿った，ややせまい部分に限ら れている．しかし内側面皮質では疎な変性域がかな り広く, 中等度変性域の背側方および後方にひろく 広がろが，背側方では分野 6 の内部へは広がらな い. しかし後方は前辺縁部，すなわち内側前核の投 射域の一部, すなわち分野 24 の前部, および分野 12 の大部分に広がろ．との領域では明らかに内側前核 の投射域と重なり合う．外側面皮質における疎な変 性域は Sylvius 前溝の下壁の内側部および後端部, ならびに露出した舟状回の後端部に広がっている.

Cat 37 (図 9)

この例では傷は背内側核の前部の高さでその腹側 の部分にあり, 背内側核の内側部, 腹側部および外 側部の境界部を占めていろ. 偒は比較的小さく, 横
に長い半月形を呈していろ. 電極は右側の大脳半球 を通って斜めに約 $20^{\circ}$ の角度で挿入され, 前室傍核 の腹側端を通り左側の背内側核に入っている.

最も強い皮質変性は前頭葉の前下縁の周囲にある. 外側面では内側面におけるよりも広く，多少前背側 方に広がっていろが, Sylvius 前溝よりかなり雅れ ていろ. 中等度の変性域は内側面においても外側面 においても強い変性域を背側および後方からおおう. 外側面の前部では一部 Sylvius 前溝の下壁の外側端 部に広がっていろ. 眯な変珄域は以上のような著明 な変性域を背側および後方からおおっていろ．この 例では皮質変性域は全体として多少前方に偏り，内 側面および外側面ともに，前端部および前部は変性 域によって占められるが, 後背側部は変性を示さな i.

Cat 4（図 10）

この例の傷は前の例におけるよりも小さく,さら にそれよりも腹内側に位置し, 全く腹側部の範囲内 にある. 前の例と同样に反対側から斜めに挿入され た電極は, 菱形核の背側端部を貫ぬいて左側の背内 側核の腹側部に達していろ. 背内側核の前後径にお けろ傷の高さは前の例よりもかなり後方に偏り, 背 内側核の中央部ないしそれよりるやや後方の高さに 限局していろ.

この例におけろ皮質変性は比較的軽い，多少著明 な変性は舟状回の外側面の前後径におけるほほ中央 部に見られ，その範囲は主として Sylvius 前溝と前 嗅溝の間にあり，ほほ卵円形を呈する，乙の皮質変 性域は背側方は一部 Sylvius 前溝の下唇をへて, そ の底の外側端部に広がっていろ. この変性域の周囲 には弱い変性域が見られるが，舟状回の前端部およ び後端部ならびに Sylvius 前溝の下壁の前内側部に は，変性は全く見られない，弱い変性域は前頭葉の 前下縁をへて内側面皮質の前下部に広がるが，かな り限局性で, 内側面皮質の背側部, 後背側部および 後部の大部分では変性がはとんど見られない。

Cat 18 (図 11)

この列では傷は同側 (左側)の大脳半球を通って垂 直に㧴入された電極によって作られ，主として背内 側核の外側部の大部分および内側部の外側端，なら びにそれらの外側に隣接した外側中心核の部分を包 含していろ，乙の傷はやや大きく，背内側核の前端 部を除く前半の高さに広がっている.

強い皮質変性は舟状回外側面皮質の前部に見られ， この変性域は多少 Sylvius 前溝に近く位置している。 
この周囲には中等度の変性域が見られる。これは背 側方は Sylvius 前溝の下展おょひ下底の外側端部に 広がろ．腹側方は前頭葉の下縁，さらに内側面皮質 の前部にかなりひろく広がっている．弱い変性域は 以上の著明な変性域のまわりにあり, 舟状回外側面 皮質の前端部, 後部および Sylvius 前溝の下壁の前 部および中央部を占めている，册状回外側面の後 $1 / 3$ では変性が見られない，内側面皮質では疎な 変性が中等度の変性の周囲を囲み, 中等度の変性域 とともにほとんど背内側核の内側面投射域の大部分 を占めているが，その後部では変性が見られない．

Cat27 (図 12)

この例では傷は同側の大脳半球を垂直に貫ぬいた 電極によって作られ，その傷は前の例よりもかなり 小さく, 腹背に長く， ほとんど背内側核の外側部に
限局し，背内側核の前後徍ではほぼその中央部の高 さを占めている.

ての例における皮質変性は原則的には Cat 18 と よく似た像を呈すが，外側面皮質の腹側部および内 側面皮質では変性が一般に軽い。このととは偒が背 内側核の外側面に限局し，内側面に波及していない ためと思われる．との例における強い変性域は舟状 回外側面の前背側部に限局していろ. 中等度の変性 域はとの強い変性域をおおって一部は Sylvius 前洅 の下唇および下壁の外側端部に広がり，さらに前頭 葉の前縁を越えて多少前頭葉内側面皮質に広がる.

弱い変性域は外側面皮曾では著明な変性域を取り巻 き，全体として舟状回の外側面皮質の前部，および 中央部ならびに Sylvius 前瑇の下壁の前部に広がっ ていろ. 内側面皮質ではその前端部の一部を除いて

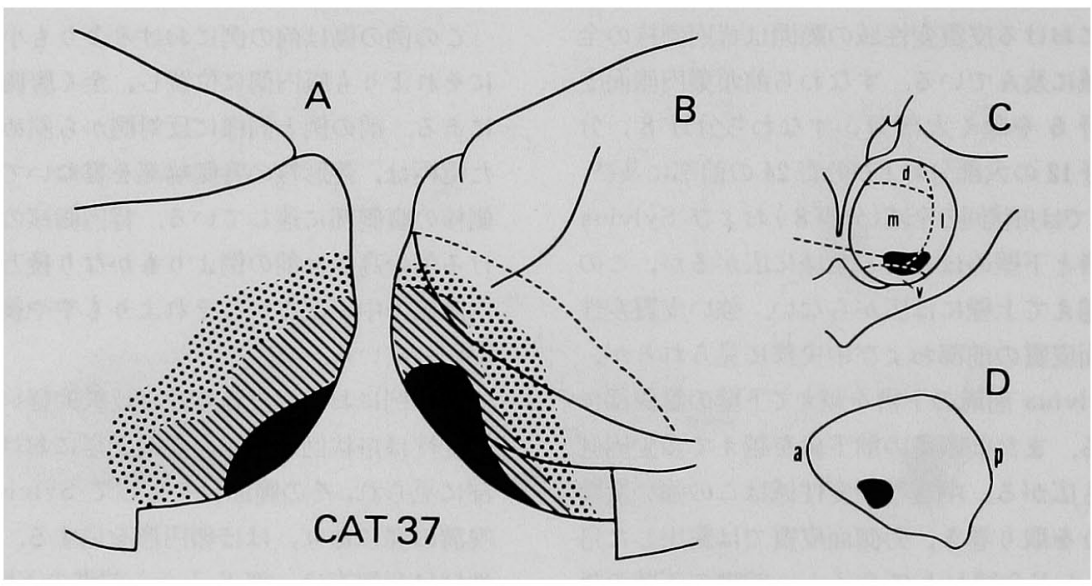

図9 Cat 37における皮質変性 (A, B)と背内側核における傷 (C, D).

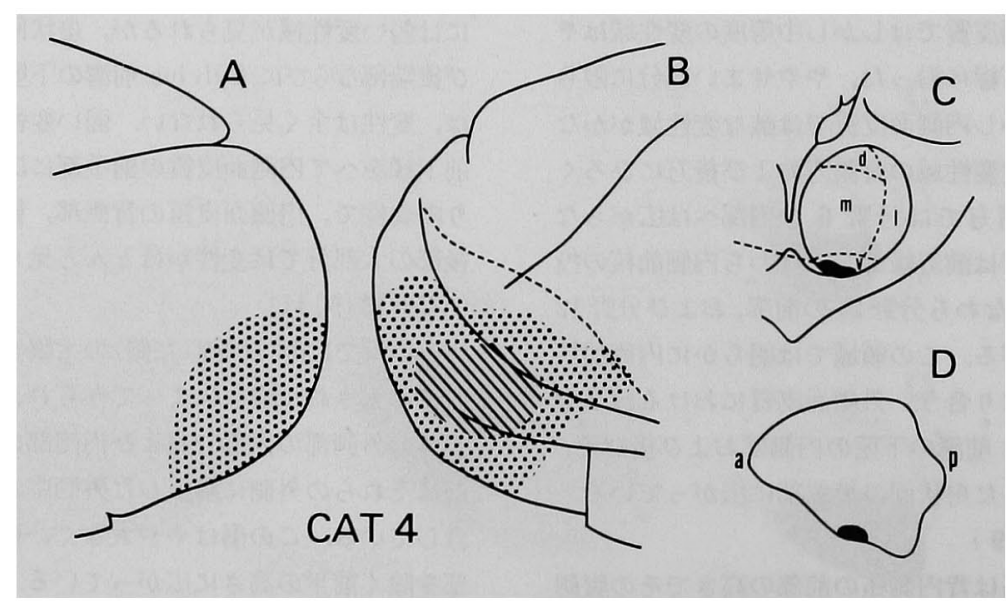

図10 Cat 4 亿おける皮質変性 (A, B)と背内側核における傷 (C, D). 
ほとんどその全域に弱い変性域が広がり，その範用 はほほCat 18 におけろ変性と同様であり,背内側核 の全投射域の大部分に広がっている.

Cat 32 (図 13)

この例は背内側核の後端部の, やや大きい破壊例 で, 電極は反対側の大脳半球を通って斜めに挿入さ れ(約 $\left.25^{\circ}\right)$ ，左側の背内側核の後端部の内側部およ び外側部にかなりひろく広がっていろ，なお傷は背 内側核の範囲を越えて多少後方に広がり，束傍核の 一部を賃つけていろ.

この例におけろ皮質変性域は背内側核の後端部の 破壊例であるにもかかわらず，背内側核のほとんど 全投射域に広がっている. しかし著明な変性域は乙 の変性域のうちで後方に偏っていることが注目され ろ. 最も強い変性域は舟状回外側面の後部で前喚溝 のまわりに見られる．乙の周囲を中等度の変性域が 取り巻き, 背側方は Sylvius 前溝の下唇に広がり, 腹側方は前頭葉の下縁をへて内側面皮質に多少広が ろ. 弱い変性域はこれらの著明な変性域上外の背内 側核の全投射域の大部分に広がっている．外側面皮 質では Sylvius 前溝の下壁の大部分に広がるが，こ の溝の底の近くでは変性は見られない，また弱い変 性は舟状回の前端にまで広がっている，内側面皮質 では分野 6 を除く前頭葉内側面皮質のほとんど大 部分に広がって，後方は前辺縁部の前部に及んでい 万.

\section{総括と批判}

Clarkと Boggon ${ }^{5)}$ がネコを用いて視床の背内側 核の前頭葉皮質への投射を Marchi 法と逆行性変性 法で研究して以来，多数の研究者によってての問題 が実験的に追求された(Waller と Barris, ${ }^{(3)}$ Waller, ${ }^{42)}$ Crouch,' Rose ¿ Woolsey," Mettler,"1 Bonin と Green,' Pribram ら, ${ }^{28}$ Nauta ¿ Whitlock, Warren $\zeta^{(4)}$, Scollo-Lavizzari と Akert, Khalifeh ${ }^{34},{ }^{\text {(2) }}$ Krieg," Wells," Narkiewicz と Brutkowski, 中,' Leonard, (15) 16) Domesick," Nauta,' Tobias $と$ Ebner, ${ }^{37)}$ Tobias, ${ }^{36)}$ Beckstead ${ }^{21}$ ). これらの研究はい ずれの動物においても背内側核は前頭葉の内側面お よび外側面にひろく投射することを認めている。

著者の実験した 13 例において背内側核の破壊に 上る皮質変性域はほほ前頭葉に限局し，外側面皮質 では舟状回（分野 8 ) およびその背側に続くSylvius 前满の下唇と下壁に限局し, Sylvius 前溝の底を越 えてその上壁に及ふてとはほとんどないが, Cat 32
のみは多少とも上壁に広がる。また内側面皮質では 背内側核の皮質投射域は分野 8 , 分野 32 の大部分, 分野 24 の前部および分野 12 の大部分を占め, 背側 方は分野 6 と境し，大部分の例では分野 6 の下界 を越えて背側方に広がるととはないが，Cat 32 のみ は多少とも分野 6 内に広がろ. 内側面皮質では変性 域は後方にかなり延び, 前辺縁部(Rose と Wool一 sey $\left.^{32)}\right)$ 前部に広がり，視床の内側前核の投射域と ある程度重なり合う。著者の実験例のうち背内側核 に最も大きい傷を有する例(Cat 22)において見られ ろ皮質変性域はほぼ背内側核の前投射域に一致する ものと考えられる.

視床背内側核の皮質投射域に関しては人によって 多少その範囲は異なる. Clark と Boggon'は)はネコで 背内側核の皮質投射域は前頭前野，外側，中間およ び内側眼窩領域であると言っている. Waller と Barris," Waller ${ }^{42)}$ らはネコで逆行性細胞変性法を 用いて研究し，両側の舟状回のはとんど完全な破壊 によって両側の背内側核のほとんど完全な逆行性細 胞変性を認めたが，背内側核の皮質投射域は舟状回 の背側部に強いと言っていろ. Rose とWoolsey ${ }^{31)}$ はネコ,ヒッジ,ウサギなどで眼窩前頭領域を細胞 構筑的に研究し, さらに背内側核からこの領域への 投射を逆行性細胞変性法を用いて追求し，背内側核 は細盷構築的に眼窩前頭領域として区画された皮質 部とほぼ一致した領域に投射すると言っている. Nauta と Whitlock ${ }^{23)}$ は Nauta 法を用いてネコの背 内側核の皮質投射を研究し, Rose と Woolsey ${ }^{311}$ と ほぼ同様，それらの線維は舟状回と内側眼窩前頭皮

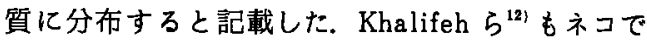
Nauta 法を用いて研究し，背内側核は舟状回，眼窩 回, 前 $S$ 状回および䐐回に分布すると言っている. またWells ${ }^{45}$ はネコの背内側核の皮質投射は分野 11，12 および 32 で強く，分野 $4 ， 6 ， 8 ， 9$ およ び10ではやや弱いと言っていろ，Khalifeh ら ${ }^{12} お$

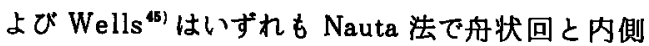
眼窝前頭領域以外の部，すなわち分野 $4 ， 6$ など に投射を認めている. 著者の例でも Cat 32 では皮質 投射域が分野 6 亿多少広がる䝨向があろ.しかし Cat 32 では傷が背内側核の後部でかなり大きく，し かも背内側核の範囲を越えて後方に広がり，束傍核 などを一部傷つけていろので決定的なことは言えな い. Waller ${ }^{421}$ は背内側核の投射域は分野 6 を越え て背側方に広かららいと言っている。

初期の研究者たちは背内側核の外側部は前頭前野 

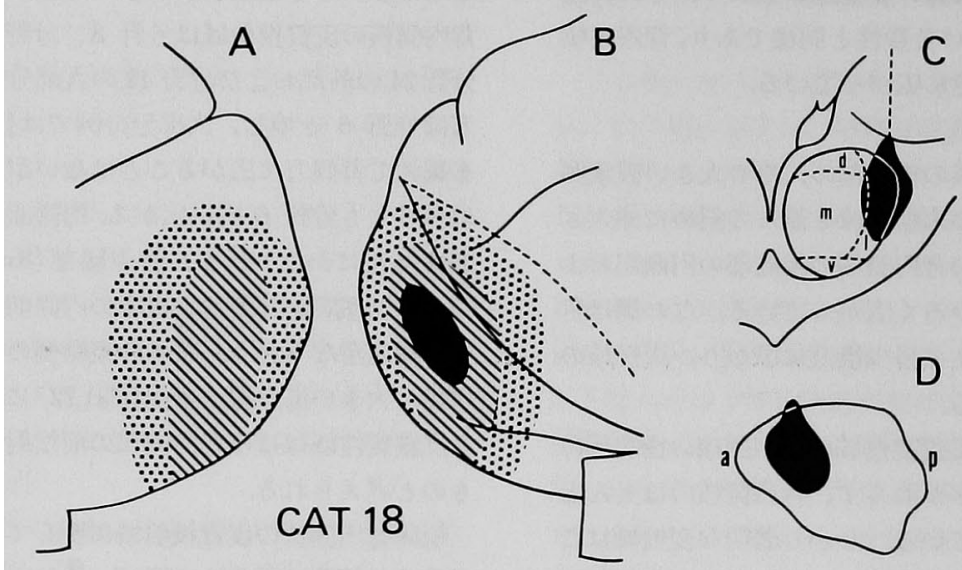

図11 Cat 18における皮質変性 $(A, B)$ と背内側核における傷 $(C, D)$.

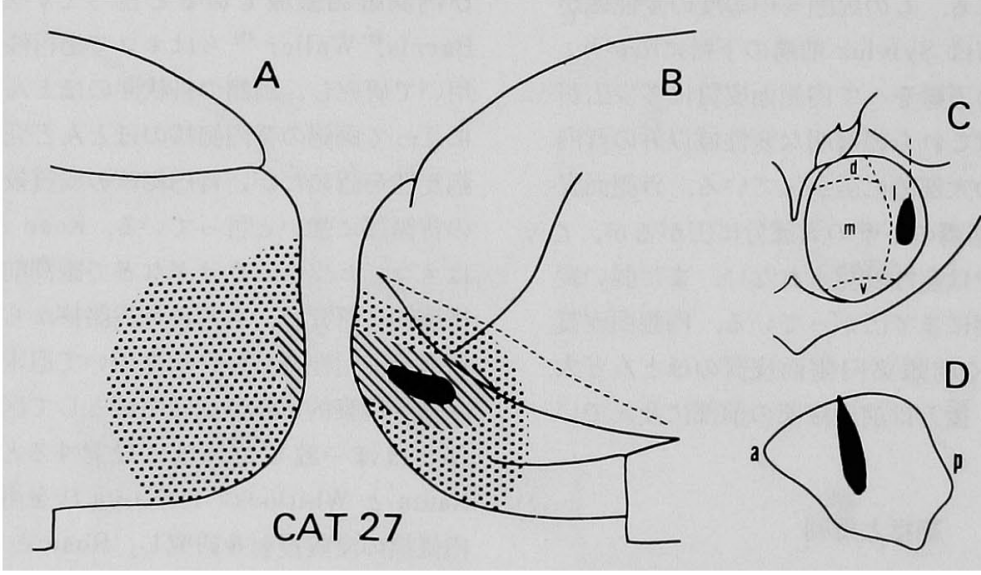

図12Cat 27における皮質変性 $(A, B)$ と背内側核における傷 (C, D).
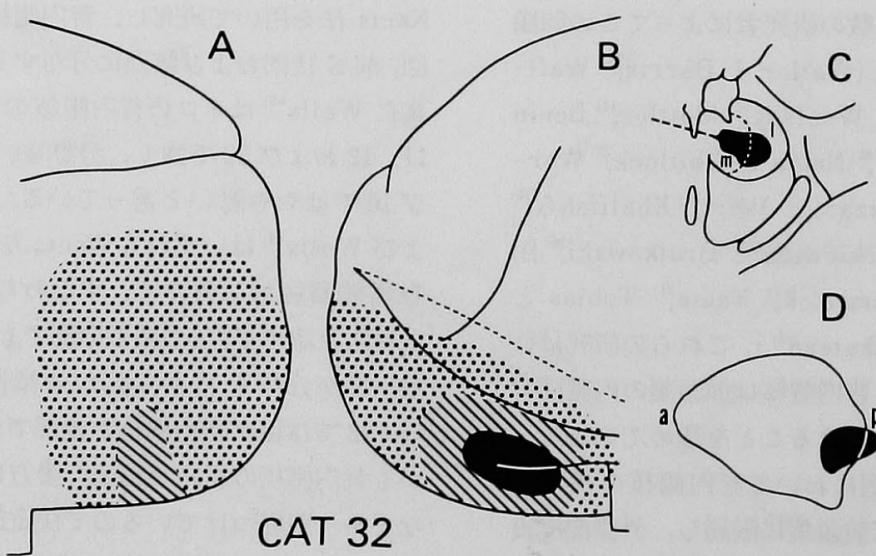

$\mathrm{D}$

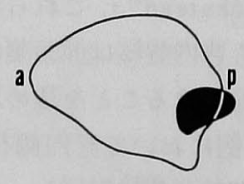

図13 Cat 32における皮質変性 (A, B) と背内側核における稘 (C, D). 


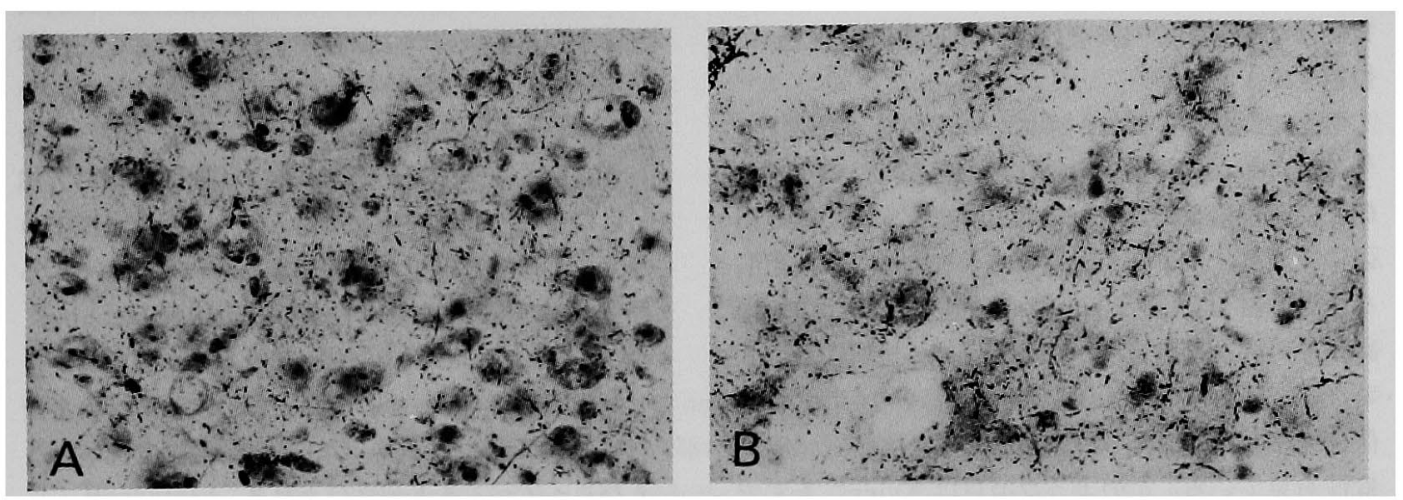

図14Cat 30(A)およびCat 18(B)におけろ皮質変性の顕微鏡写真.Aは前頭葉内側面 皮質第 4 層, Bは前頭葉外側面皮質における第 4 層. $\times 250$.

の外側面に投射するが，背内側核の内側部は前頭前 野に投射しないと考えていた(Clark と Boggon, Walker $^{\text {3s) }}$ ). Walker ${ }^{(0)}$ はクロショウショョウで背内 側核の内側部も前頭葉の眼窩皮質に投射を行なうこ とを示し，さらにWaller ${ }^{42)}$ むコで背内側核の内 側部が皮質投射を行なうととを見い出した。

背内側核の部位によろ皮質投射の相違，すなわち 皮質投射の局在性については，いまだ十分解明され ているとは言い難い，著者の所見によると，傷が背 内側核の内側部と背側部にあろ例 (Cats 53, 39, 30, $17,34,6)$ では強い変性は舟状回外側面皮質の背 側部と Sylvius 前溝の下壁に見られる. 背内側核の 外側部之腹側部に傷のある例(Cats $4,18,27$ )では 強い変性は舟状回外側面皮質の腹側部之前頭葉内側 面皮質に見られろ.このことは背内側核の部位によ ろ投射に相違のあることを示し，特に内外側の方向 に局在性があることを示すものと考えられる.Walker $^{\text {(9) }}$ Waller (2) らちすでにてのような背内側核の皮 質投射の局在性の存在を示唆し，背内側核の内側部 は前頭葉顆粒皮質の後下部へ，背内側核の外側部は 前頭葉顆粒皮質の前上部に楾維を送ると言っている. 田中 ${ }^{351}$ は背内側核の外側部は前頭葉外側面皮質に, 背内側核の内側部は内側面皮質に投射すると言って いろが, 著者の所見では, 背内側核の外側部(腹側部 を含む)の投射域之内側部(背側部を含む)の投射域 の境界はほぼ前嗅㴗およびその前方延長線であると 考えられる. Narkiewicz と Brutkowski ${ }^{201}$ は逆行性 細胞変性法によってィヌの背内側核の皮質投射を研 究し，背内側核の中間部は前頭面皮質の最前部に， 背内側核の後外側部は舟状回と眼窩回の後部に, 背
内側核の前内側部は前頭前皮質の内側面に投射する と言っている.

著者の所見はさらに背内側核の前後の方向におけ ろ局在性を示唆する。すすわち背内側核の前部の傷 (Cats 53，18，37，27）では変性は前頭前皮質の前 部に強く，背内側核の中央部の傷 (Cats 39，30，17， 4 )では前頭葉の中央部に強く, 背内側核の後部の傷 (Cats 34，35，33，32) では前頭葉の後部で変性が 强い傾向があろ. Walker ${ }^{39)}$ (1) はサルで背内側核の 皮質投射には前後の方向に局在性があると言ってい ろ. 田中 ${ }^{35)}$ はネコで著者と同じような所見を得てい ろ.しかし Warren ら“"の所見は著者の結果とかな り異なる.すなわち彼らはネコで逆行性変性法を用 いて背内側核の皮質投射を研究し，背内側核の前極 は大这半球の内側面の眼窩前頭皮質の後部に, 背内 側核の赤道部は前頭極に, 背内側核の後極は Sylvius 前溝に接した，またはその溝の中の外側眼窩前 頭皮質に投射すると言う。しかし著者の例では，背 内側核の中央部の傷では前頭葉の前極には変性が非 常に軽いか全くない. また背内側核の前部(ないし 前端)の傷で強い変性が前頭葉内側面皮質後部(ない し後極)に見られる例はない。

背内側核の皮質投射の局在性に関してはサルにつ

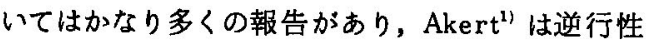
細胞変性法を用いて研究し，サルの背内側核を大細 胞部，小細胞部および髄板傍部に分かち，これらは それそれ眼筒部, 分野 9 および分野 8 に投射する と言っていろ. 最近 Tobias ${ }^{301}$ はオートラジオグラ フィ一法を用いて背内側核の皮質投射を研究し，そ の外側部は前頭葉の背外側の凸面へ，背内側核の内 
側部は前頭前野の腹側部 (眼窩部) 人, 背内側核の尾 背側部は前頭葉の内側壁(背内側前頭前野を含む)に 投射すると言う.

著者の所見によろと,ネコの背内側核の腹側部は 外側部に似た皮質投射を行ない, 背側部は内側部に 似た皮質投射を行なうが，これらの部がいかなる前 頭葉皮質部に主として投射するかに関しては決定的 なととは言えない. Nauta ${ }^{21}$ はサルで扁桃体の線維 結合を研究した論文の中で背内側核の皮質投射に及 れ, 背内側核の内側部の腹側の部(おそらく著者の腹 側部に相当)の傷の例で腹側 (眼窩) 前頭前野に皮質

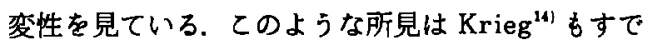
に報告していろ. Tobias ${ }^{36)}$ は背内側核の腹側部のア イソトープ注入例で眼窩皮質および外側皮質に銀粒 子の分布を見ていろ. 著者の背内側核の腹側部破壊 例(Cat 4 )では前嗅溝より背側に著明な変性が見ら 九，外側部の破壊例におけろ所見と本質的な差異を 認めがたい.

Nauta ${ }^{21)}$ も Krieg ${ }^{\text {(0) }}$ も背内側核の背側部に傷を作 っていないが, Tobias ${ }^{361}$ はサルの背内側核の背側部 に限局した注入例で, 大脳半球上縁部のまわりの内 側皮質と外側皮質に銀粒子の分布を見ていろ. Ake$\mathrm{rt}^{1 / 1}$ はしかしこのような背内側皮質の剩離では背内 側核に逆行性細胞変性を証明していない，著者の未 コにおけろ実験のうち Cats 53，34，35 では背内側 核の背側部が障害され，いずれの例でも強い変性は 前頭葉内側面皮質と外側面皮質の境界部に見られる. 以上のように著者のネコにおけろ所見では背内側核 の皮質投射におけろ腹背側の方向の局在性は証明さ れなかったが，Walker (1) はサルで背内側核の皮質 投射の腹背側の方向における局在性の存在を示唆し ている。

なお前頭葉以外の皮質の剥離で背内側核に逆行性 変性が見られたという報告がある，Waller ${ }^{(2)}$ はネコ の冠状回の腹側端の傷で背内側核の外側部に逆行性 細胞変性を認めた。 著者の例のうち Cat 32 では Sylvius 前溝を越えてその上壁にまで変性が多少とも広 がろ. この例では背内側核の内側部のみならず，外 側部も強く破壊されているが，傷が外側部のみに限 局した例(Cat 27) では変性は Sylvius 前溝の底を越 えて上壁にははとんど及ばない。したがってての問 題に関しては著者の実験の範囲では決定的なととは 言えない. Scollo-Lavizzari と Akert" はサルで は背内側核の投射域は顆粒前頭皮質の境を越えて弓 状㸺の前壁を作ろ移行領域を含むという.
以上の上うに背内側核の著明な皮質投射には前後 および内外側の方向に局在性が認められるが，傷が あろ一定以上の大きさの時には背内側核のいずれの 部分に賃を有する例でも，その傷に応じた部位にお ける著明な変性のはか背内側核の皮質投射域の大部 分にびまん性の弱い投射が見られろ.これは視床の 連合核(非特殊核)では一般に認められるもので，外 側核および枕核では著明である(Niimi と Inoshita, Niimi $~^{26)}$ ). また背内側核におけろ傷が非常に小さ い例(Cats 53，35，4)では変性が背内側核の全投 射域に広がるととはいが, 比較的弱い変性がかな りひろく広がることが注目される。

背内側核の皮質投射線維は一般にかなり細く，そ の皮質終末の分布に関しては原則的にはいずれの例 も同様であろ.すなわちこれらの線維は主として第 4 層および第 3 層の深層に分布するが, 第 5 層お よび第 6 層でも終末が見られる，また第 1 層の表 層でも少数の線維終末が見られろ.特に第 1 周の終 末は背内側核破罗例の前頭葉では他の視床核破畷例 におけろよりもわずかに多いように思われる.

\section{結 語}

著者はネコの視床背内側核の皮質投射を NautaGygax 法および Fink-Heimer 法を用いて研究した。 背内側核は内側部，外側部，背側部および腹側部に 分がれる．その皮質投射域は外側面皮質では舟状 回と Sylvius 前溝の下壁に広がり，内側面皮質では 舟状回から背側方は分野 6 の下端に及び，また後方 は前辺縁部の前部に広がろ，背内側核の強い皮筫投 射には明らかに前後の方向に局在性がある．背内側 核の各部からの皮質投射域には非常に強い重なり合 いがあろが，背内側核の内側部および背側部の傷の 例では著明な皮質変性域は前頭葉内側面皮質から外 側面皮質にお゙けろ舟状回の腹側端部にかけて見られ， これに反し背内側核の外側部および腹側部の傷の例 では著明な皮質変性域は舟状回の外側面の背側部お よび Sylvius 前漊の下壁に認められろ.このことは 背内側核の著明な皮質投射には内外側の方向に局在 性があろことを示唆する.内側部(背側部を含む)と 外側部(腹側部を含む)の著明な投射域の境界はほほ 前嗅溝およびその前方延長部に相当する．背内側核 の皮質投射の背腹側の方向における局在性は認めが たい，背側部および腹側部のおもな皮質投射域を正 確に決定するととは困難であるが，背側部は主とし て前頭葉の内側面と外側面の境界部 (前下縁)に投射 
する㑯向があろ. 背内側核は以上のような強い局在 性皮質投射をなすと同時に，弱い沉性皮質投射を行 なう。すなわち傷が一定の大きさ以上であれば，背 内側核はそのどの部分の破壊によってもその部位に 応じ強い皮質変性を起こすと同時に，背内側核の
投射域の大部分に広がろ散在性の皮質変性を示す傾 向がある.

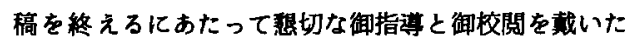
新見教授に心から感謝いたします。

文献

1) Akert, K.: Comparative anatomy of frontal cortex and thalamofrontal connections. The frontal cortex and behavior. ed. by Warren and Akert, McGraw-Hill, New York, 372-396, 1964.

2) Beckstead, R. M.: Convergent thalamic and mesencephalic projections to the anterior medial cortex in the rat. J. Comp. Neurol., 166:403-417, 1976.

3 ) Bonin, G. and Green, J. R.: Connections between orbital cortex and diencephalon in the macaque. J. Comp. Neurol., $90: 243-254,1949$.

4 ) Clark, W. E. Le Gros: The structure and connections of the thalamus. Brain, 55:406-470, 1932.

5) Clark, W. E. Le Gros and Boggon, R. H.: On the connections of the medial cell groups of the thalamus. Brain, $56: 83-98,1933$.

6 ) Crouch, R. L.: The efferent fibers of the thalamus of Macacus rhesus. J. Comp. Neurol., 72 : 177-186, 1940.

7 ) Domesick, V. B.: Thalamic relationships of the medial cortex in the rat. Brain, Behav. Evol., $6: 457-483,1972$.

8 ) Fink, R. P. and Heimer, L.: Two methods for selective silver impregnation of degenerating axons and their synaptic endings in the central nervous system. Brain Res., $4: 369-374$, 1967.

9 ) Gerebtzoff, M. A.: Systématisation des connexions thalamo-corticales des aires frontales, centrales et pariétales. Cellule, 46:7-54, 1937.

10) Gurewitsch, M. und Chatschaturian, A.: Zur Cytoarchitektonik der Grosshirnrinde der Feliden. Z. Anat. u. Entw. gesch., $87: 459-596,1928$.

11) Jasper, H. H. and Ajmone-Marsan, C. A. A stereotaxic atlas of the diencephalon of the cat. Nat. Res. Council Publ., Ottawa, 1954.

12) Khalifeh, R. R., Kaelber, W. W. and Ingram, W. R.: Some efferent connections of the nucleus medialis dorsalis. An experimental study in the cat. Amer. J. Anat., $116: 341-353,1965$.

13) Krettek, J.E. and Price, J.L.: The cortical projections of the mediodorsal nucleus and adjacent nuclei in the rat. J. Comp. Neurol., $171: 157-192,1977$.

14) Krieg, W. J. S.: Thalamic afferents to the frontal lobe of the Macaque. Intern. J. Neurol., $5: 317-329,1966$.

15) Leonard. C. M.: The prefrontal cortex of the rat. I. Cortical projection of the mediodorsal nucleus. II. Efferent connections. Brain Res., 12:321-343, 1969.

16) Leonard, C. M.: The connections of the dorsomedial nuclei. Brain, Behav. Evol., $6: 524-$ 541, 1972.

17) Mettler, F. A.: Extracortical connections of the primate cerebral cortex. J. Comp. Neurol., $86: 95-117,1947$.

18) Minkowski, M.: Étude sur le connexions anatomiques des circonvolutions rolandiques, pari- 
etales et frontales. Schweiz. Arch. Neurol., 12:71-104, 1923.

19) Monakow, C. von: Experimentelle und pathologisch-anatomische Untersuchungen über den Haubenregion, den Sehhügel und die Regio subthalamica. Arch. Psychiat., $27: 1-128,386$ $-478,1895$.

20) Narkiewicz, 0 . and Brutkowski, S.: The organization of projections from the thalamic mediodorsal nucleus to the prefrontal cortex of the dog. J. Comp. Neurol., 129:361-347, 1967.

21) Nauta, W. J. H. : Neural associations of the amygdaloid complex in the monkey. Brain, 85: $505-525,1962$.

22) Nauta, W. J. H. and Gygax, P. A. : Silver impregnation of degenerating axons in the central nervous system: A modified technic. Stain Technology, 29:91-93, 1954.

23) Nauta, W. J.H. and Whitlock, D. G.: An anatomical analysis of the nonspecific thalamic projection system. Brain Mechanisms and Consciousness. ed. by J. F. Delafresnaye, Blackwell, Oxford, 1954.

24) Niimi, K. and Inoshita, H.: Cortical projections of the lateral thalamic nuclei in the cat. Proc. Japan Acad., 47:664-669, 1971.

25) Niimi, K. and Kuwahara, E.: The dorsal thalamus of the cat and comparison with monkey and man. J. Hirnforsch., $14: 303-326,1973$.

26) Niimi, K., Kadota, M. and Matsushita, Y.: Cortical projections of the pulvinar nuclear group of the thalamus in the cat. Brain, Behav. Evol., $9: 422-457,1974$.

27) Niimi, K., Kishi, S., Miki, M. and Fujita, S.: An experimental study on the course and termination of the projection fibers from cortical areas 4 and 6 in the cat. Fol. psychiat. Jap., $17: 167-216,1963$.

28) Pribram, K. H., Chow, K. L. and Semmes, J.: Limit and organization of the cortical projection from the medial thalamic nucleus in monkey. J. Comp. Neurol., 98:433-448, 1953.

29) Rioch, D. McK.: Studies on the diencephalon of carnivora. Part I. The nuclear configuration of the thalamus, epithalamus, and hypothalamus of the dog and cat. J. Comp. Neurol., 49: $1-119,1929$.

30) Rioch, D. McK.: Studies on the diencephalon of carnivora. Part III. Certain myelinated-fiber connections of the diencephalon of the dog, cat, and aevisa. J. Comp. Neurol., 53:319-388, 1931.

31) Rose, J.E. and Woolsey, C. N.: The orbitofrontal cortex and its connections with the mediodorsal nucleus in rabbit, sheep and cat. Proc. Assn. Res. Nerv. Ment. Dis., $27: 210-232$, 1947.

32) Rose, J. E. and Woolsey, C. N.: Structure and relations of limbic cortex and anterior thalamic nuclei in rabbit and cat. J. Comp. Neurol., 89:279-348, 1948.

33) Sachs, B.: Ein vergleichend anatomische Studie des Thalamus opticus der Säugetiere. Arb. neur. Inst. Wien, 17:280-306, 1909.

34) Scollo-Lavizzari, G. and Akert, K.: Cortical area 8 and its thalamic projection in Macaca mulatta. J. Comp. Neurol., $121: 259-267,1963$.

35）田中収：ネコの視床背内側核の遠心路に関する実験解剖学的研究，岡山医学会雑誌, $81: 369-383,1969$.

36) Tobias, T. J. : Afferents to prefrontal cortex from the thalamic mediodorsal nucleus in the rhesus monkey. Brain Res., 83:191-212, 1975.

37) Tobias, T.J. and Ebner, F. F.: Thalamocortical projections from the mediodorsal nucleus in the Virginia opossum. Brain Res., 52:79-96, 1973.

38) Walker, A. E.: The thalamus in relation to the cerebral cortex. J. nerv. ment. Dis., 85: 
249-261, 1937.

39) Walker, A.E.: The primate thalamus. Univ. of Chicago Press, Chicago, 1938a.

40) Walker, A. E. : The thalamus of the chimpanzee. N. Thalamic projections to the cerebral cortex. J. Anat., $73: 37-93,1938$ b.

41) Walker, A. E. : The medial thalamic nucleus. A comparative anatomical, physiological and clinical study of the nucleus medialis dorsalis thalami. J. Comp. Neurol., 73:87-115, 1940.

42) Waller, W. H.: Thalamic connections of the frontal cortex of the cat. J. Comp. Neurol., 73 $: 117-138,1940$.

43) Waller, W. H. and Barris, R. W.: Relationship of thalamic nuclei to the cerebral cortex in the cat. J. Comp. Neurol., $67: 317-342,1937$.

44) Warren, J.M., Warren, H. B. and Akert, K. : Orbitofrontal cortical lesions and learning in cats. J. Comp. Neurol., $118: 17-41,1962$.

45) Wells, J.: The pathway from the dorsomedial thalamus to the frontal lobe. Exp. Neurol., 14 : 338-351, 1966. 


\section{An experimental-anatomical study on the cortical projections of the dorsomedial nucleus of the thalamus in the cat Masaji TOMONARI}

Third Department of Anatomy, Okayama University Medical School, Okayama, Japan

(Director : Prof. K. Niimi)

The present study attempts to clarify the cortical projection of the dorsomedial thalamic nucleus with the use of the Nauta-Gygax and Fink-Heimer methods. The dorsomedial nucleus is composed of dorsal, medial, lateral and ventral parts. Its cortical projection areas are the lateral prorean cortex and the lower bank of the presylvian sulcus, as well as the medial frontal cortex extending from the prorean gyrus to the cortical part just ventral to area 6 dorsally and to the rostral portion of the anterior limbic region caudally. Although there is an apparent overlap between the cortical projections from the different parts of the dorsomedial nucleus, the dorsomedial nucleus projects to the frontal cortex in a topical manner anteroposteriorly. In cases with lesions in the medial and dorsal parts, marked cortical degeneration is found in the medial frontal cortex and the ventral portion of the lateral prorean cortex, whereas in cases with lesions in the lateral and ventral parts marked degeneration is detected in the dorsal portion of the lateral prorean cortex and the lower bank of the presylvian sulcus. This suggests that there is a mediolateral organization in the cortical projection of the dorsomedial nucleus. The boundary between the marked projection areas of the medial (and dorsal) and the lateral (and ventral) parts may be represented by the anterior rhinal sulcus and its rostral extension. No evidence of a topical organization in the dorsoventral direction is found in the cortical projections of the dorsomedial nucleus. In addition, it is difficult to determine to which area of the frontal cortex the dorsal or ventral part projects. However, the dorsal part tends to send fibers largely to the anteroinferior margin of the frontal lobe. Each part of the dorsomedial nucleus may be said to have both localized and diffuse projections to the frontal cortex. That is, if the lesion is not so small, the localized lesions anywhere in each part of the dorsomedial nucleus tend to cause diffuse scattered degeneration in almost the whole extent of the cortical projection area of the dorsomedial nucleus, in addition to dense localized degeneration which varies with the site of the lesion. 